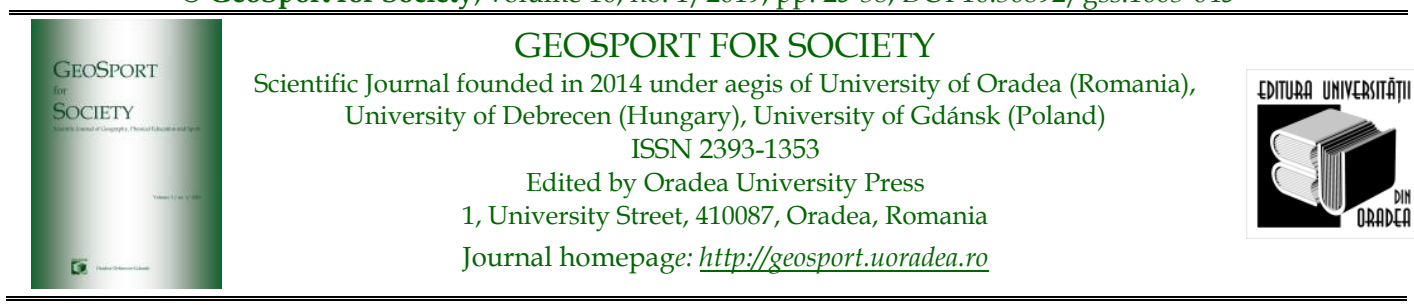

\title{
The appearance of product innovation in the life of a Hungarian SMEs in the global market of sporting goods - implications from a research
}

\author{
Kornélia V. MÓRIK ${ }^{1}$, Éva BÁCSNÉ BÁBA 2 , Anetta MÜLLER ${ }^{3}$, Gergely Gábor \\ RÁTHONYI ${ }^{4}$, Anikó MOLNÁR 5*
}

1. University of Debrecen, Department of Sports Management, Faculty of Economics and Business, Böszörményi street 138., 4032, Debrecen, Hungary, e-mail: nellymorik@gmail.com

2. University of Debrecen, Department of Sports Management, Faculty of Economics and Business, Böszörményi street 138., 4032, Debrecen, Hungary, bacsne.baba.eva@econ.unideb.hu

3. University of Debrecen, Department of Sports Management, Faculty of Economics and Business, Böszörményi street 138., 4032, Debrecen, Hungary, muller.anette@econ.unideb.hu

4. University of Debrecen, Department of Agricultural Informatics, Faculty of Economics and Business, Böszörményi street 138., 4032, Debrecen, Hungary, rathonyi.gergely@econ.unideb.hu

5. University of Debrecen, Department of Sports Management, Faculty of Economics and Business, Böszörményi street 138., 4032, Debrecen, Hungary, e-mail: miller.e.annie@gmail.com

* Corresponding author

Citation: Mórik, V. K., Bácsné Bába, E., Müller, A., Ráthonyi, G.G., Molnár, A. (2019). The appearance of product innovation in the life of a Hungarian SMEs in the global market of sporting goods-implications from a research. Geosport for Society, 10(1), 25-38. https://doi.org/10.30892/gss.1003-045

Article history: Received: 07.01.2019; Revised: 20.03.2019; Accepted: 20.04.2019, Available online: 08.05.2019

\begin{abstract}
For a Hungarian SME to keep its already acquired position in the global market of sporting goods is a continuous and complex task in which innovation plays a key factor. The purpose of our research is to certify the necessity and the appearance of innovation in the life of a product in the sports business - this case concerning the production of NAJADE fins. This work helps to identify the trends of the consumer attitudes, which is an essential information in product development. The result of the survey $(\mathrm{N}=200)$ regarding the needs of consumers shows that however product design plays a secondary role to the quality, durability and the results reached with the product, it is still an influencing factor in product selection. Since sports equipment are used to achieve better results with, the technical improvement of the product is an important aspect of product innovation. Furthermore, the biological acceleration of the generations and the specific needs of the different kind of underwater sports should be taken into consideration when manufacturing these products. Moreover, to reach lower income, developing countries with our products, cheaper, cost-effective technological proceedings could mean a solution.
\end{abstract}

Keywords: sport, innovation, underwater sports, sporting goods, product innovation 


\section{Introduction}

In the global market of sporting goods, international competition is quite strong for Hungarian companies. A good portion of this market is ruled by the Far East, but the United States gets its share as well. For a Hungarian product to keep its already acquired position, get more customers, and to expand, it is essential to continuously develop its products and to monitor and analyze the participants of the market and even the market itself.

Nowadays innovative thinking and co-operation play a significant role in increasing the competitiveness of domestic SMEs and multinationals. Because of this reason, the importance of the role of innovation with producing sporting goods should be emphasized. In the field of sport, the diverse profiles of product development require the content of innovation, which in exchange enables companies applying it to achieve better results (Könyves and Müller, 2007).

In addition to product innovation, it is also important to mention marketing innovation, which refers to the novel application and combination of "marketing tools" as a result of which consumers have new products, better shopping situations, other advertising, etc. (Bauer and Berács, 2001). Besides producing and distributing the products, it is of great importance for the distributing company to carry out sport marketing activities. "The two main areas of sports marketing are the sale of services and sporting goods directly to consumers of sport, and the sale of industrial products and services using sport as a promotional tool" (Mullin et al., 1993).

In this research, we aimed to map out the popularity of the different types of NAJADE fins used in underwater sports. To meet the needs of customers, it was our priority to look at the observations of the competitors regarding these sports equipment. Based on these results our main focus was on product innovation. Our goal was moreover to examine the most common factors affecting the purchase of these fins, including size selection, product design, color, material, comfort, the results achieved with the examined product, and what would the athletes change about our products.

\section{Theoretical background}

The traditional course of product development changed over time completely (Rohács, 1997). While the traditional process started with an idea and progressed towards producing and sales, modern product development starts from consumer needs. The market clearly specifies what product do they need, on what price and with what characteristics.

The global business of the sports industry is growing rapidly and has been providing numerous entrepreneurial opportunities. The dynamic nature and scope of sports industry development and the growing market make it critical for SMEs to compete for consumers in need for them to stay alive. According to Chikán (2008), innovation is the act of customer satisfaction on a new, higher quality level. To get more customers, SMEs need to meet the demands of the potential buyers. This can be achieved by producing better than rival companies in every aspect (material, quality, durability, functions, etc.). 
The prerequisite of the success of businesses is the ability of the adaptation to changes (Chikán, 2008). Companies need to offer their product, so as customers will be willing to pay for it more than for the products of the competitors.

By the definition of OECD (Organization for Economic Co-operation and Development, 2005) "An innovation is the implementation of a new or significantly improved product (good or service), or process, a new marketing method, or a new organizational method in business practices, workplace organization or external relations".

The Oslo Manual for measuring innovation defines four types of innovation (Katona, 2006). Product innovation: A good or service that is new or significantly improved. This includes significant improvements in technical specifications, components, and materials, software in the product, user-friendliness or other functional characteristics.

Process innovation: A new or significantly improved production or delivery method. This includes significant changes in techniques, equipment, and software.

Marketing innovation: A new marketing method involving significant changes in product design or packaging, product placement, product promotion or pricing.

Organizational innovation: A new organizational method in business practices, workplace organization or external relations.

In this study, our main focus falls on product innovation (figure 1). As a result, product innovation could provide sustainability in a rapidly growing sports industry sector. With this type of development profit and market share can be increased, prestige can be improved since it is an effective way to increase sales with expanding the circles of customers, as well as regular customers. Moreover, last, but not least as a collateral externality product innovation can create new jobs as well (figure 1).

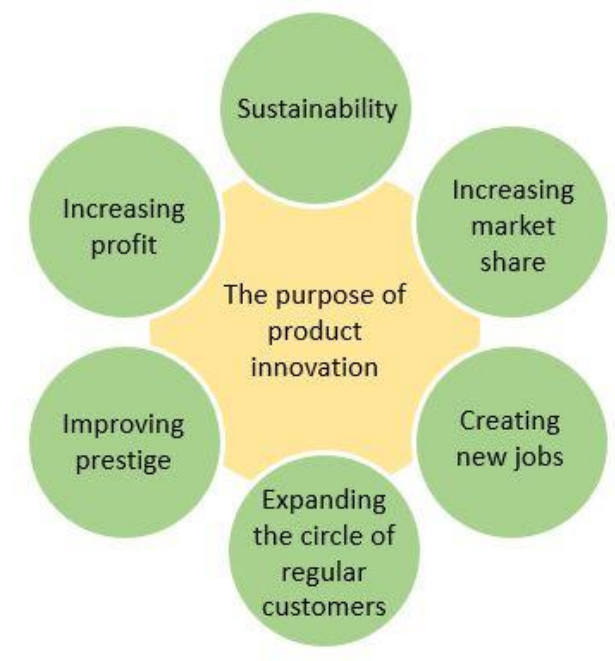

Figure 1. The purpose of product innovation

Source: Own editing based on Szakály - Innovation management (2013)

Based on their source of origin we can categorize product innovation in two groups, namely the demand-driven: demand-pull, and the technological knowledge induced: technology push. 
Change in customer needs can generate knowledge-change, as certain customer needs direct developers towards new solutions. The pressure of the customers, as a motivational factor has a crucial importance in this. Professionals analyzing the market, state that those companies who have the potential to develop need to have the following three types of customers (Szakály, 2013): profit-making, stable customers; volume growth ensuring "joiners"; change enforcing "cognoscentsi".

To the utilization of the available knowledge, those present in the market contribute to the highest degree, but to start the knowledge-change new customers are needed.

This change in the needs of the customers, with the changing market environment and the new social needs, create new products, or the modification or improvisation of an existing product because it is intended to satisfy those changing needs. In this aspect new products can be categorized by the following order (Szakály, 2013): product with a new function; old product with new performance; existing product with the utilization of a new technology; new, complementary function; transfer to a new market; integration of old products into a new product; simplification of an existing product to create mass-product; dissembling of an existing product to new components; newly designed product. However, it is not enough to simply develop the "new product". As previous researches show the success rate of the introduction of a new product to the market is below $25 \%$ on the average (Nagy, 2013). This means the more in-depth we know the key factors in the success of the product- and service-innovation, the better chance we have, to achieve better results than our competitions in the market.

Henard and Szymanszky (2001) identified five key product characteristics as the predictors of new product performance on the market: 1 . Product advantage, which comes from the superiority and differentiation over competitive offerings; 2 . Product meets customer needs: the extent of which product is perceived as satisfying desires/needs of the customer;3. Product price, as perceived price-performance congruency (value); 4. Product technological sophistication, the percieved technological sophistication (high-tech, low tech) of the product; 5. Product innovativeness, the percieved newness / originality / uniqueness / radicalness of the product (figure 2).

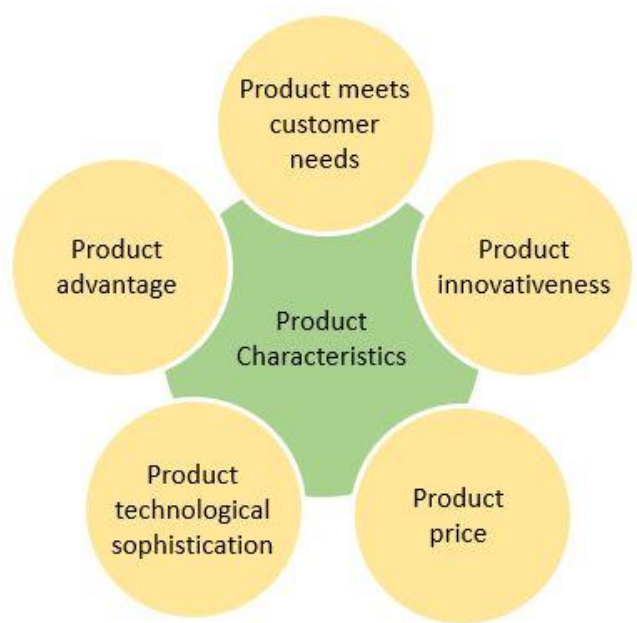

Figure 2. Predictors of new product performance by product characteristics Source: Own research (2019) 


\section{Introducing the product}

The popularity of water sports (Bíró et al., 2015) is illustrated by the fact that more and more literature deals with its development or the methodological aspects of its organization. The increase in the number of water sports shows that its mass base is widening and the demand is increasing.

The CMAS, the World Underwater Federation oversees ten underwater sports including Apnoea, Aquathlon, Finswimming, Underwater Hockey, Underwater Rugby, Orienteering, Visual, Spearfishing, Sports Diving, CMAS Games (CMAS, 2018). In all of which athletes use different types of rubber fins. However, besides the typical users, we have to mention lifeguards, and hobby divers as well as the swimmer and the water polo who also use rubber fins for their workouts, which can help them to improve foot muscle and improve foot technic. NAJADE fins are among the sports products that feature both product features and service features at the same time, and also appear as promotional tools (Hoffman, 2000). The manufacturing and distribution company is a sports company, i.e., a company that works in the field of sport to meet consumer needs while achieving a profit (András, 2003).

Continuous monitoring of trends in the field of sport and recreation is important because it can affect the competitiveness of SMEs. These trends reflect the current consumer habits in the field of sport, which are important for product development. In the field of sport and fitness, such trends are uniqueness and style, or the need for comfort and quality that influences customers in product selection both with sports equipment and services (Müller, 2009; Müller et al., 2013; BorbélyMüller, 2015; Müller et al., 2017).

In addition to the production and distribution of the sporting goods, our company is also engaged in sports sponsorship to promote its products (Bíró et al., 2015), doing so through several international underwater sports competitions such as World Cups, European and World Championships in which underwater hockey, water rugby athletes are given free products. In this way, it reaches its promotional and marketing goals (Mullin et al., 1993, p. 208). In exchange for the sponsorship, advertising space may be requested from the organizers, and from the sponsored national athletes to take part in the competitions wearing the NAJADE logo.

Since the NAJADE fins manufacturing company has been present on the international market for seven years, it is likely that during this time the needs and expectations of the athletes against the product have changed, which can be supported by the market research conducted.

The downward price strategy is probably a good choice, as it does not affect the purchasing decision of the professional athletes, but the price differentiation is likely to be necessary, as well as the development of lower-priced products. The latter are mostly demanded by the athletes in the developing countries, as well as in countries with lower discretionary income and lower GDP (such as Egypt, India). Paár (2013) states that in the case of a decline in household income, the reduction in the price of sports products can compensate for the negative trend in demand reduction, although this alone is not enough for a rapid increase in demand, but it must be a sports policy that NAJAD can achieve with different price differentiation with different discretionary income. Customers in countries with a declining or declining consumer income. 
During the research, we were looking for answers to the following questions:

- How do the needs of different underwater sports develop against the fin? How can fins meet the needs of different underwater sports?

- How are the buying habits of athletes in different underwater sports and what are the most important aspects that influence the purchase?

- What innovation opportunities do we have for the NAJADE fins company in product development based on expectations from athletes?

\section{Material and methods}

The data for our primary research was collected via questionnaires. The questionnaire has been compiled to provide answers to the factors influencing product selection in different types of underwater sports. We created open-ended and close-ended questions. To examine the influencing the effect of different factors we have created a five-point Likert in which, one is the least, and five the most typical statement for the respondents.

The questionnaires were filled out in our consumer circles, on paper in Hungarian, English and Russian language. They were collected from the following international swimming competitions:

- World Cup Eger, Coral Springs / Florida / United States;

- Junior World Championship Tomsk / Russia;

- Adult Europe Championship Wroclaw / Poland;

- 2018 Adult World Championship) Belgrade / Serbia;

- Junior European Championships in Istanbul / Turkey;

- U19 and U23 World Championships in Hobart / Tasmania / Australia;

- Adult Europe Championship Eger - 2018 Championship Teams Europe Cup Castellon / Spain;

- Adult World Cup Quebec City / Canada

The operative work was carried out with the help of the SPSS statistical data analysis program, in which descriptive statistical analyzes dominate (mean, standard deviation, median, mode).

In addition to descriptive statistics, we used the Chi-square cross table test to determine the relationship between two variables.

\section{Introducing the sample}

In the end, 211 questionnaires were filled out successfully, from which after datacleaning, 200 was used. After analyzing the socio-demographic section, we received the following picture of the respondents. $55.5 \%$ of them (111 people) are women, $44.5 \%$, or 89, are men, with an average age of 23.76 (standard deviation 7.234).

As NAJADE fins are primarily Hungarian products, it is not surprising that the largest percentage (13\%) of our consumer range is provided by Hungarian customers. In the second place, Canadian and Colombian partners are represented by $9-9 \%$, but a good portion of customers from the leading nations Italy (7\%), Argentina $(4 \%)$ and the United States (4\%) are also present (figure 3).

As for the distribution within underwater sports, the NAJADE fin manufacturing company targets three major sports with its products (of course, not disclosing any other water sports). Because of this reason in our questionnaire, only the three 
targeted sports are represented (Finswimming, Underwater Hockey and Underwater Rugby). Table 1 shows that almost half of the respondents $(48,5 \%)$ are Finswimmers.

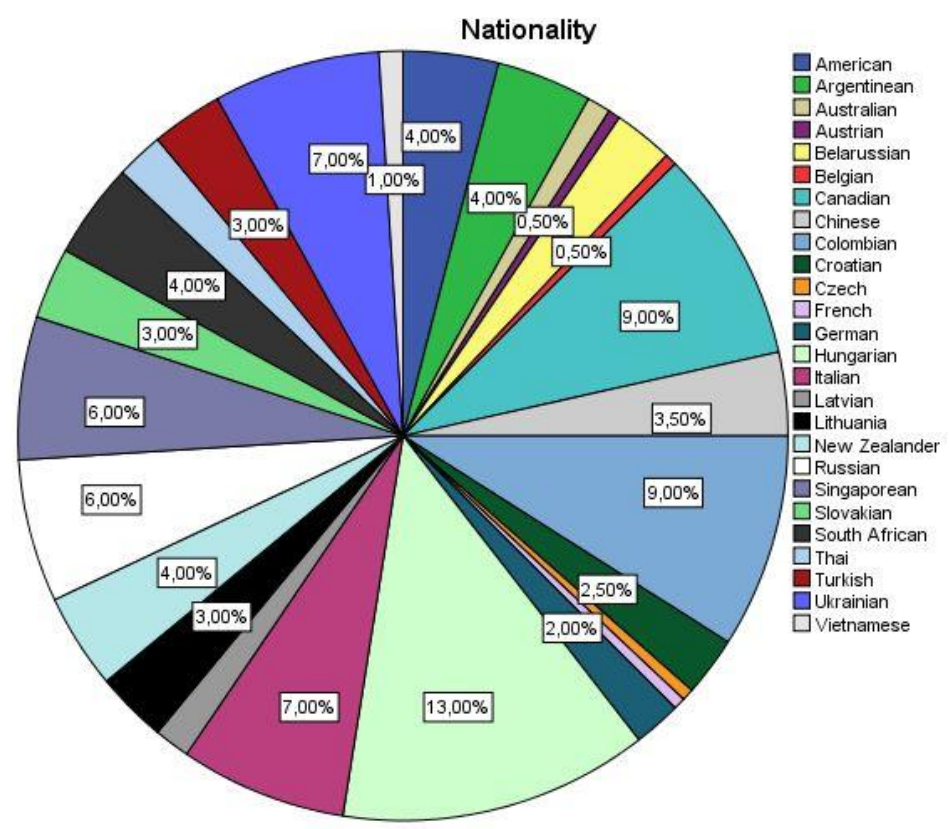

Figure 3. Nationalities of the customer circle Source: Own research (2019)

\begin{tabular}{|l|c|c|}
\hline & $\begin{array}{c}\text { Frequency } \\
\text { (Persons) }\end{array}$ & $\begin{array}{c}\text { Percent } \\
\text { (\%) }\end{array}$ \\
\hline Finswimming & 97 & 48,5 \\
\hline Underwater Hockey & 59 & 29,5 \\
\hline Underwater Rugby & 44 & 22,0 \\
\hline Total & 200 & 100 \\
\hline
\end{tabular}

Table 1. The frequency of the respondents in different types of underwater sports (2019)

Source: Own editing (2019)

The results corroborate to the presence of a long-standing trend in the underwater community. Finswimming is the cheapest of the 3 mentioned sports, due to its low equipment need. Also, Finswimming has fewer financial implications, thus enabling the wider masses and less well-off classes to get involved. Furthermore, it is important to mention the fact that underwater sports are the first in the New Countries because their base is swimming, they are spectacular and give more opportunities to compete in.

There is another reoccurring trend about the age of the athletes and what type of underwater sports do they participate in 


\begin{tabular}{|c|c|c|}
\hline Sport of respondents & $\begin{array}{c}\text { 16-23 age bracket } \\
\% \text { (persons) }\end{array}$ & $\begin{array}{c}25-50 \text { age bracket } \\
\% \text { (persons) }\end{array}$ \\
\hline Finswimming & $98(95)$ & $2(2)$ \\
\hline Underwater Hockey/Rugby & $30,1(31)$ & $69,9(72)$ \\
\hline
\end{tabular}

Table 2. Coherency between the age of the participants and their sports (2019) Source: Own research (2019)

Among Finswimmers, the younger age group appears to be more active, from the age of 16 to the age of 23 . These athletes usually stop their active career (as in most competitive sports) at the end of their academic studies. This trend can also be seen from our research, as the majority of the finswimmers, (98\%) are from the age group of 16-23, while in the 25-50 age group a drastic decline could be seen (table 2).

The base of our research and questionnaire are the products of NAJADE. Based on the use in major underwater sports and on sales statistics, we examined the following 4 product categories: Speed, Sprint, Iron and UW.

As the name of the equipment indicates, the use and design of the Speed and Sprint fins makes the product types used for Finswimming (where speed is the most important factor). In contrast, Iron and especially UW fins are products made of harder and stiffer material, which makes them more suitable for underwater rugby and underwater hockey.

The majority of respondents prefer SPEED and SPRINT products (24\% - 38\%), which can be explained by the fact that they are used by Finswimmers, who have shown a higher percentage of involvement out of the 3 mentioned sports. IRON and UW products were picked by nearly the same number of respondents $(18.5 \%$ and $19.5 \%)$. In order to examine the factors affecting the purchase, we have created a 5point Likert-scale, in which one is the least, 5 is the most influential factor on the respondents (figure 4).

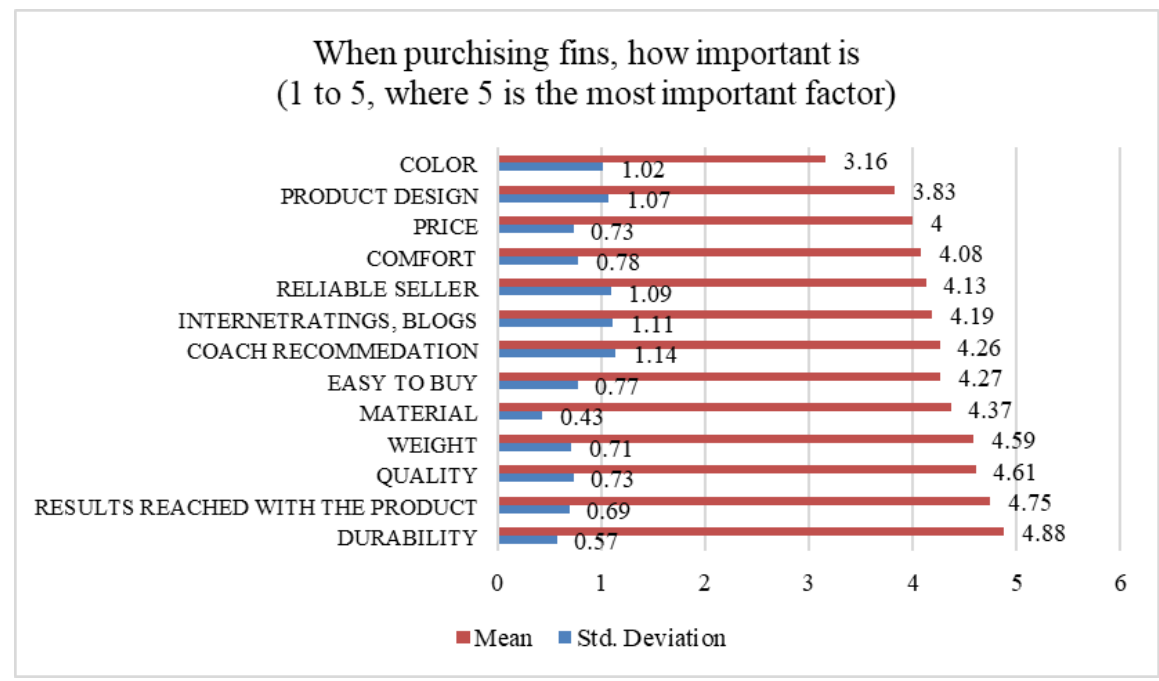

Figure 4. Factors influencing product purchase (2019) Source: Own research (2019) 
From the collected data, it is remarkable (not surprisingly) that the first three highest rated factors are: durability (4.88), results reached with the product (4.75) and quality (4.61). This supports Torkos' (2009) statement, who reports on the product development strategy of the most successful fitness machine manufacturers, where innovation and durability of products are named as development priorities.

Since we are talking about sports equipment that we use to achieve sporting results, the appearance of the products (color: 3.16; design: 3.83) plays a secondary role. This can also be said about the price of the products (4), since those who want to achieve better results want quality, and durable products are willing to pay for a possibly more expensive, better tool.

In the interest of innovation and product development, we also asked our customers what would they change on/about the products of NAJADE.

Urbanization and civilization can speed up the acceleration of children and young adults (Eiben-Tóth, 2005; Bodzsár-Zsákai, 2015), thus with changing anthropometric factors (even younger athletes have larger foot size they are taller and more advanced, so naturally they need larger fins with different fin-density) the expectations of the athletes' are changing as well.

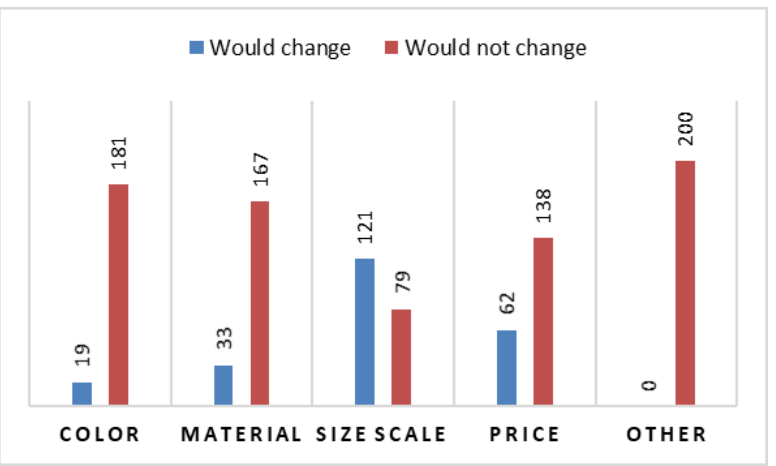

Figure 5. What would you change about NAJADE fins? (2019)

Source: Own research (2019)

Generational change can be demonstrated in body size, which increases the height of the foot and increases the foot size (Frenkl-Mészáros, 2002; Bodzsár-Zsákai, 2002; Bodzsár et al., 2015; 2016). Changes in physical fitness also require the manufacturers of sports products to adapt, as the manufacturers of sportswear and sports equipment must also take this trend into account when designing the scale of the product range due to increasing height and foot size.

\section{Results of correlation tests}

Based on the Pearson Chi-square test, the two variables are significant $(<0.05)$. The value of the Chi-square is ( $\chi 2$ ) 84,342, while the degree of freedom (df) is 6 . From the results, it can be observed that there are differences in the sport-specific design of the fins. Specially designed for underwater rugby and underwater hockey, IRON, and UW fins show a higher percentage in this category $(40,7 \% ; 34.1 \% ; 31.8 \%$; $28.8 \%$ ) (table 3). 


\begin{tabular}{|c|c|c|c|c|}
\hline \multicolumn{5}{|c|}{ Which Type/Types of NAJADE fins you have? } \\
\hline Your Sport & $\begin{array}{c}|c| \\
\text { Finswimming } \\
\text { person (\%) }\end{array}$ & $\begin{array}{c}\text { Underwater } \\
\text { Hockey } \\
\text { person (\%) }\end{array}$ & $\begin{array}{c}\text { Underwater } \\
\text { Rugby } \\
\text { person (\%) }\end{array}$ & $\begin{array}{c}\text { T0TAL } \\
\text { person (\%) }\end{array}$ \\
\hline SPEED & $33(34,0)$ & $8(13,6)$ & $7(15,9)$ & $48(24)$ \\
\hline IRON & $6(6,2)$ & $17(28,8)$ & $14(31,8)$ & $37(18,5)$ \\
\hline SPRINT & $58(59,8)$ & $10(16,9)$ & $8(18,2)$ & $76(38)$ \\
\hline UW & $0(0)$ & $24(40,7)$ & $15(34,1)$ & $39(19,5)$ \\
\hline Total & $97(100)$ & $59(100)$ & $44(100)$ & $200(100)$ \\
\hline
\end{tabular}

Table 3. he correlation between the sport of the respondents and the type of fins they use (2019) Source: Own research (2019)

SPEED and SPRINT products are also present but only a small amount, as they are suitable for training, conditioning and based on individual preference judges of underwater sports also use these types of fins. This can also be said about the relationship between Finswimming, SPRINT and SPEED products.

As in all areas of commercial products, consumer demands are differentiated by gender (pink / blue shoes, etc.) from a very young age. This also the case with sports products (Nike Women's/ Men's line). In order to be able to serve our customers at the highest possible level of satisfaction, it is important to consider gender preferences.

Identifying the gender characteristics is essential both for satisfying customer needs and for producing the equipment for which the demand is present in the market. To do this, we must first look at the gender distribution in each sport. The results of the survey of the sexes of the respondents and the sport they participate in are presented in table 4 .

\begin{tabular}{|c|c|c|c|}
\hline & \multicolumn{2}{|c|}{ GENDER } & \\
\hline Your Sport & $\begin{array}{c}\text { FEMALE } \\
\text { person (\%) }\end{array}$ & $\begin{array}{c}\text { MALE } \\
\text { person (\%) }\end{array}$ & $\begin{array}{c}\text { TOTAL } \\
\text { person (\%) }\end{array}$ \\
\hline Finswimming & $62(55,9 \%)$ & $35(39,3 \%)$ & $97(48,5 \%)$ \\
\hline Underwater Hockey & $31(27,9 \%)$ & $28(31,5 \%)$ & $59(29,5 \%)$ \\
\hline Underwater Rugby & $18(16,2 \%)$ & $26(29,2 \%)$ & $44(22,0 \%)$ \\
\hline Total & $111(100 \%)$ & $89(100 \%)$ & $200(100 \%)$ \\
\hline
\end{tabular}

Table 4. Distribution of gender in relation to the three targeted sport (2019)

Source: Own research (2019)

Based on the Pearson Chi-square test, it can be stated that the two variables are significant $(<0.05)$. The value of the Chi-square is $(\chi 2) 6,785$, while the degree of freedom (df) is 2 .

From the results, we can conclude that the majority of women $(+16.6 \%)$ prefer finswimming, while the number of them in underwater rugby is much lower $(-13 \%)$, which can be taken into consideration when manufacturing gender specified product lines in different type of underwater sports (table 5). 


\begin{tabular}{|c|c|c|c|}
\hline & \multicolumn{2}{|c|}{ GENDER } & \\
\hline $\begin{array}{c}\text { Please mark on a scale } \\
\text { of 1-5, if 1 is the least } \\
\text { and 5 is the most } \\
\begin{array}{c}\text { typical statement } \\
\text { when purchising fins, } \\
\text { how important is } \\
\text { COLOR }\end{array}\end{array}$ & $\begin{array}{c}\text { FEMALE } \\
\text { person (\%) }\end{array}$ & $\begin{array}{c}\text { MALE } \\
\text { person (\%) }\end{array}$ & $\begin{array}{c}\text { TOTAL } \\
\text { person (\%) }\end{array}$ \\
\hline 2 & $26(23,4 \%)$ & $30(33,7 \%)$ & $56(28,0 \%)$ \\
\hline 3 & $52(46,8 \%)$ & $39(43,8 \%)$ & $91(45,5 \%)$ \\
\hline 4 & $16(14,4 \%)$ & $3(3,4 \%)$ & $19(9,5 \%)$ \\
\hline 5 & $17(15,3 \%)$ & $17(19,1 \%)$ & $34(17,0 \%)$ \\
\hline Total & $111(100 \%)$ & $89(100 \%)$ & $200(100 \%)$ \\
\hline
\end{tabular}

Table 5. Color scale as an influencing factor in purchasing NAJADE fins (2019) Source: Own research (2019)

In Finswimming for example, where the study showed more female participants, the manufacturer could extend the line of product especially aimed at women. We have examined the various factors influencing the purchase and gender relations of these purchasing habits. The presence of color as an influencing factor can be considered a significant result.

Based on the Pearson Chi-square test, it can be stated that the two variables are significant $(<0.05)$. The value of the Chi-square is $(\chi 2) 8,723$, while the degree of freedom (df) is 3. It can be said that the color of the fins is the more important aspect for women. Men, however, are more influenced on the size scale and comfort of products (table 6).

This issue can be broken down to Sports and influencing factors as well. The underwater rugby and hockey games are longer. Thus, the athletes participating in these games wear their fins longer. The feel of the IRON and UW products need to be suitable and comfortable for longer use.

\begin{tabular}{|c|c|c|c|}
\hline & \multicolumn{2}{|c|}{ Gender } & \\
\hline $\begin{array}{c}\text { Is there anything that you } \\
\text { would modify on Najade fins? - } \\
\text { Size scale }\end{array}$ & $\begin{array}{c}\text { FEMALE } \\
\text { person (\%) }\end{array}$ & $\begin{array}{c}\text { MALE } \\
\text { person (\%) }\end{array}$ & $\begin{array}{c}\text { TOTAL } \\
\text { person (\%) }\end{array}$ \\
\hline Yes & $54(48,6 \%)$ & $67(75,3 \%)$ & $121(60,5 \%)$ \\
\hline No & $57(51,4 \%)$ & $22(24,7 \%)$ & $79(39,5 \%)$ \\
\hline Total & $111(100 \%)$ & $89(100 \%)$ & $200(100 \%)$ \\
\hline
\end{tabular}

Table 6. Size scale as an influencing factor in purchasing NAJADE fins (2019)

Source: Own research (2019)

Based on the Pearson Chi-square test, it can be stated that the two variables are significant $(<0.05)$. The Chi-square value is (2) 14,660, while the degree of freedom (df) is 1 .

\section{Conclusion}

Initially, while NAJADE had a monopoly on the market, the downward price strategy proved to be good, but the emergence of competitors, as well as the increasing price sensitivity of buyers, and the fact that more and more low-cost 
African and Asian countries are joining in the underwater sports community prompts the distributor to reconsider its price strategy.

It is clear that $93 \%$ of the respondents consider the quality of the equipment important when purchasing the product and $80 \%$ of the consumers take into account the previous results achieved with the fins, which is due to the excellent quality of the product. Satisfying customer needs is important for products, as quality is what the customer recognizes. Quality, if a product can meet consumer needs (Parasurman et al., 1985; Giubilato et al., 2013).

During the sponsorship and personal visit of different competitions, there is an opportunity for direct sales, contacts with customers and the completion of questionnaires during such competitions. $23 \%$ of the interviewees bought the fins directly from the manufacturer during the competitions. This greatly increases the amount of product sold and the visibility of the product.

Since their launch, NAJADE products have realized a growing turnover, which, with the help innovation, is trying to satisfy consumers' needs as fully as possible. The most important aspect of product development was to incorporate the needs and experiences of top athletes into the development (Senánszky Petra world champion tested and indicated the development needs of a swimmer to achieve the best possible result in that sport). With this market research, we measured the needs of several underwater sports athletes for the product. If we can accommodate these needs, the company can expect even greater demand in the future. Increase in demand could be led by innovation (Drucker, 2003; Pakucs-Papanek, 2006), with which NAJADE targets new markets (new countries, new underwater sports). In the future, such plans will include the use of fins among lifeguards, as many European countries will also compete with NAJADE fins, and will use a suitably designed product for classical swimming, swim-out, teaching, and improving competition. In water polo, the company continues its product launch with fins used in training. Water polo is a TAO sport in Hungary (Sárközy, 2017; Kendelényi - Gulyás, 2018), so its youth base is growing dynamically, which may also mean an increase in demand.

It is also necessary to change the composition of the fin material, which is also a possible form of innovation. Different rubber strengths can be developed in different areas of the fin, and combining them allows us to meet the sport-specific needs of different underwater sports.

The research has also shown that there is a need for different sizes of fins, we need to expand the size range, as there is the typical problem with footwear, that one size is small, but the next one is big, so the need to introduce intermediate sizes has arisen - for example, the introduction of 2.5 to 3.5. The 46-48-foot size is not uncommon among the athletes, so the 5th size should be introduced in manufacturing.

Experience gained in market research will help to further renew fins and possibly open them to new markets, which is also needed to create marketing strategies (Kovács, 2012; Józsa, 2014).

It is noticeable that more and more non-underwater sports countries are starting to develop and compete in underwater sports, such as India, Central African countries, and Brazil, Ecuador, Peru, which gives us more opportunities to open up to 
new markets. The athletes in these countries are still very price sensitive, so it is advisable for them to develop a new product line under the NAJADE brand, which results in cheaper technology production. Experience in market research shows that design and color matter more to younger generations and with this development, greater success can be achieved if the new product line comes into the market with vibrant design elements (Mórik - Müller, 2018).

Of course, the range of opportunities is unlimited, but even for NAJADE products, these product innovations require investment, which is coupled with a substantial capital requirement that the manufacturer is trying to satisfy, as innovation is the foundation of competitiveness (Könyves - Müller, 2007).

\section{Acknowledgment}

This study was supported by the EFOP-3.6.2-16-2017-00003 project which is financed by the European Union and the European Social Fund.

\section{References}

András, K. (2003). The connections of sports and business - theoretical bases. Budapesti Közgazdaságtudományi és Államigazgatási Egyetem, Budapest 43 p. (in Hungarian).

Bauer, A., \& Berács, J. (2001). Marketing. Aula Kiadó, Budapest, 620 p.

Bíró, M., Müller, A., \& Szalay, G. (2015). Organising sport events. (szerk: Müller Anetta)(ISBN 978-6155297-30-4) 100 p. (in Hungarian).

Borbély A., \& Müller A. (2015). Sports and Tourism. 110 p. Campus Kiadó, Debrecen, ISBN 978-963-982236-8 (in Hungarian).

Bodzsar, E. B., \& Zsakai, A. (2002). Some aspects of secular changes in Hungary over the twentieth century. Collegium antropologicum, 26(2): 477-484.

Bodzsar, É, Zsakai, A, \& Mascie-Taylor, N. (2016). Secular Growth And Maturation Changes In Hungary About Socioeconomic And Demographic Changes. Journal Of Biosocial Science, 48(2): 158-173.

Bodzsar, E. B., Zsakai, A., Utczas, K., \& Mascie-Taylor, C. N. (2015). The biological status of children living in disadvantaged regions of Hungary. Journal of biosocial science, 48(3), 306-321.

Chikán, A. (2008). Business Economics, Aula Kiadó, Budapest, 31 p.

Drucker, P. F. (2003). The opportunities of innovation. Harvard Business Manager, 5: 28-34 (in Hungarian).

Eiben, O. G., \& Tóth, G. A. (2005). A Hungarian case of secular growth changes: the Körmend Growth Study. Ind. J. of Phys. Anthrop. and Hum. Gen. 24(2): 99-108.

Frenkl, R., \& Mészáros, J. (2002). The motoric secular trends; the physical performance of puberty aged boys. Sportegészségügy, 4(5): 294-297 (in Hungarian).

Giubilato, F., Petrone, N., \& Franch, V. (2013). A method for the quantitative correlation between quality requirements and product characteristics of sport equipment. Procedia Engineering, 60, 403-408.

Henard, D. H., \& Szymanski, D. M. (2001). Why some new products are more successful than others. Journal of marketing Research, 38(3): 362-375.

Hoffmann, I. (2000). Sportmarketing. Budapest: Bagolyvár Könyvkiadó. 200.p. ISBN: 9639197645

Józsa, L. (2014). Marketing strategies. Akadémiai Kiadó, Budapest, 394 p (in Hungarian).

Katona, J. (2006). The evaluation of the Third Edition of the Oslo Handbook, Budapest, 3-4. p

Kendelényi-Gulyás, E. (2018). The connections of the competitiveness of Hungarian professional sports and the efficienty of the state founding (Doctoral dissertation, Testnevelési Egyetem).

Kovács, Zs. (2012). The role of finswimming and underwater swimming in the meaningful use of leisure time. PTE TTK Testnevelés- és Sporttudományi Intézet, Pécs, 59 p (in Hungarian). 
Könyves, E., \& Müller, A. (2007). Innovative cooperation in leisure sports. In: Acta Academiae Pedagogicae Agriensis. XXXIV. Kötet. 71-81 (in Hungarian).

Mórik, K., \& Müller, A. (2018). Role and importance of the innovation of sport products development concerning NAJADE type rubber fins. In: Jaromír, Šimonek; Beáta, Dobay (szerk.) Sport science in motion : proceedings from the scientific conference. Športová veda v pohybe: recenzovaný zborník vedeckých a odborných prác z konferencie. Mozgásban a sporttudomány: válogatott tanulmányok a konferenciáról.Komárno, Szlovákia : Univerzita J. Selyeho, (2018) pp. 299-308. , 10 p.

Mullin, B. J., Hardy, S., \& Sutton, W. A. (1993). Sports Marketing. Human Kinetics Publisher Canada.

Müller, A. (2009). The latest trends in sports marketing and managebent. In: Magyar Sporttudományi Társaság Sportinnovációs Szakbizottság Évkönyve, 59-63.

Müller, A., \& Bíró, M. (2015). Organizing Sports Events. EKF, Líceum Kiadó, Eger, 49 p. ISBN 978-6155297-73-1.

Müller, A., Bíró, M., Hidvégi, P., Váczi, P., Plachy, J., Juhász, I., Hajdú, P., \& Seres, J. (2013). Fitness trends in recreation. In: Acta Academiae Agriensis. XL. 25-35 (in Hungarian).

Müller, A., Bíró, M., Bodolai, M., Hidvégi, P., Váczi, P., Dávid, L., \& Szántó, Á. (2017). The 2016 fitness trends place and role of recreation. Acta Academiae Paedagogicae Agriensis Nova Series: Sectio Sport, 44: 91102 (in Hungarian).

Nagy, Sz. (2013). Analysis of factors determining the success of new products in the market, Conference: Kiterjesztett marketing: Magyar Marketing Szövetség Marketing Oktatók Klubjának XIX. Országos Konferenciája. 824 p. Budapest, Magyarország, 2013.08.28-2013.08.29. Budapesti Gazdasági Főiskola, 2013. p. 11.,

OECD, (2005). "The Measurement of Scientific and Technological Activities: Guidelines for Collecting and Interpreting Innovation Data: Oslo Manual, Third Edition" prepared by the Working Party of National Experts on Scientific and Technology Indicators, OECD, Paris, para. 146.

Paár, D. (2013). The economic standing-point analysis of the Hungarian households' sports consumption (Doctoral dissertation, nyme) (in Hungarian).

Pakucs, J., \& Papanek, G. (2006). Innovation management manual. Magyar Innovációs Szövetség, Budapest, $233 \mathrm{p}$.

Parasuraman, A., Zeithaml, V. A., \& Berry, L. L. (1985). A conceptual model of service quality and its implication for future research. Journal of Marketing, 49 (April), pp. 41-50.

Rohács, J. (1997). The Role of Universities in Technology Transfer, Naucno Strucni Skup Vozduhoplovstvo'97, Beograd, pp. E11 - E16. 1997.

Sárközy, T. (2017). Sport as a Strategic Sector in the National Economy. Benefits, Drawbacks and LongTerm Perspectives. Polgári Szemle: Gazdasági és Társadalmi Folyóirat, 13(4-6), 143-159 (in Hungarian).

Szakály, D. (2013). Innovation management, Miskolc, Miskolci Egyetem Gazdaságtudományi Kar, 263 p.

Torkos, Z. (2009). Designing the world's best fitness equipments with focus on health prevention, in the centre of life fitness in Budapest. In. XIV. fiatal műszakiak tudományos ülésszaka. Kolozsvár, 2009. március 26-27 (in Hungarian). https://eda.eme.ro/bitstream/handle/10598/13399/14_FMTU2009\%20_\%20Torkos\%20Zoltan\% 20_\%20221-224\%20old.pdf?sequence=1\&isAllowed=y.

Web-sites sources:

http://www.cmas.org/cmas/about 